\title{
PERENCANAAAN STRATEGI PENINGKATAN LAYANAN PERGURUAN TINGGI DENGAN METODE QFD (QUALIY FUCTION DEPLOYMENT) STUDI KASUS: PG PAUD FIP UNJ
}

\author{
Nurbiana Dhieni \\ Azizah Muis
}

\begin{abstract}
Penelitian bertujuan untuk mengidentifikasi keinginan dan kebutuhan konsumen, kualitas pelayanan PGPAUD UNJ menurut persepsi pelanggan; mengidentifikasi isu-isu strategis dan membuat usulan strategi peningkatan kualitas layanan dengan Metode QFD. Metodologi yang digunakan dalam penelitian ini adalah survey, yang meliputi: pemberian angket, wawancara dan focus group. (1) Harapan terhadap terhadap layanan di PGPAUD UNJ adalah kualitas SDM yang menunjang (dosen dan karyawan) sehingga mampu memberikan layanan pendidikan dan administrasi yang baik: 14,28\%; Pembelajaran berlangsung dengan interaktif didukung dengan kurikulum yang sesuai dengan perkembangan IPTEKs dan tuntututan kerja: 26,19\%; Efektifitas pengelolaan dan keramahan dalam melayani mahasiswa: 9,52\%; Lulus dengan tepat waktu dengan kualitas penelitian yang baik: 9,52\%; Ketersediaan sarana dan prasarana perkuliahan:35,72\%; Pencitraan publik dengan memanfaatkan/membuat media informasi:4,77\%; (2) Kinerja PG PAUD FIP UNJ dalam memberikan pelayanan pendidikan dinilai kurang memuaskan. Hal ini dapat terlihat dari tingginya gap antara ekspektasi dan persepsi terhadap kualitas layanan. Gap terbesar adalah 4 sebanyak 2,08\%, gap 3 sebanyak 41,67\% dan (3) Relevansi dan daya saing dapat memenuhi kebutuhan pelanggan sebesar 33,687\%. Penguatan tatakelola dan akuntabilitas $28,291 \%$. Pencitraan publik memiliki konstribusi dalam memenuhi kebutuhan pelanggan adalah 16,435\% dan pengembangan sumber daya manusia memiliki porsi sebesar 21,832\%.. (4) Proses perencanaan strategi dibuat usulan strategi dan penyebarannya samapi level 2 dalam struktur organisasi PGPAUD UNJ. Usulan tersebut terdiri dari 13 strategi pada level pertama dan 57 strategi pada level kedua.
\end{abstract}

Kata Kunci: Perencanaan Strategi, QFD, PGPAUD

\section{PENDAHULUAN}

Jurusan PG PAUD FIP UNJ memberikan layanan jasa pendidikan dengan mengemban misi tri dharma perguruan tinggi. Penilaian terhadap performa kualitas atribut-atribut produk (barang maupun jasa) penting dilakukan. Untuk itu identifikasi dan pendefinisian apa yang menjadi atribut-atribut pelayanan perlu memperhatikan keinginan konsumen (customer requirements). Setelah diketahui, perlu dilakukan penilaian terhadap performan kualitas atribut-atribut tersebut. Dalam menyusun langkahlangkah perbaikan, perlu diperhatikan prioritasprioritas respon teknikal serta karakteristik proses yang berhubungan customer requirements. Data yang diperoleh untuk mengukur tingkat kepuasan sangatlah subjektif, mengingat hal sangat berhubungan dengan persepsi tiap individu yang dipengaruhi oleh pengalaman, latar belakang, dan lain sebagainya. Untuk menekan penyimpangan akibat subyektifikat setiap individu, maka diperlukan sebuah analisis dengan QFD (Qualiy Fuction Deployment).

Untuk melakukan peningkatan kualitas pelayanan pendidikan di Jurusan PG PAUD FIP UNJ, beberapa masalah yang dapat diidentifikasi adalah: (1) Apa yang menjadi atribut pelayanan PG PAUD FIP UNJ? Atribut pelayanan tersebut haruslah mencerminkan kebutuhan mahasiswa sebagai konsumen (customer requirements). (2) Bagaimana performa kualitas atribut pelayanan PG PAUD FIP UNJ?

\section{KAJIAN TEORI}

\section{Kualitas Jasa}

Jasa merupakan suatu produk yang intangible dan ada bersamaan dengan permintaan konsumen, oleh karena itu pengadaan jasa tidak dapat disimpan dan jika tidak digunakan konsumen berlalu begitu saja. Menurut D.P Tampubolon (1995), jasa peguruan tinggi meliputi (1) jasa kurikulum, (2) jasa penelitian, (3) jasa pengabdian kepada masyarakat, (4) jasa ekstra- 
kurikuler, (5) jasa administrasi, dan (6) jasa kebijakan umum. Sementara itu, agar pelaksanaan jasa perguruan tinggi dapat terlaksana, maka haruslah ada beberapa hal yang menunjang, antara lain (1) sumber daya manusia, (2) material, (3) peralatan, (4) lingkungan, dan (5) prosedur

\section{Quality Fuction Deployment (QFD)}

QFD merupakan salah satu metode untuk pengembangan produk atau jasa berdasarkan tingkat kepuasan konsumen dari pengguna barang/jasa. QFD adalah sebuah proses interdisciplinary team dalam merencanakan desain atau improve dan proses: (1) fokus pada kebutuhan konsumen, (2) faktor lingkungan kompetitif dan market/konsumen menjadi pertimbangan keputusan, (3) interfuctional team work, (4) permintaan konsumen di tafsirkan sehingga menjadi tujuan yang terukur untuk setiap departemen, dan (5) seluruh tenaga kerja menyimpan kata"mendengarkan suara konsumen".

Tujuan QFD adalah translate permintaan konsumen sehinga disebut dengan "voice of the consumer (VOC) menjadi karakteristik final produk atau jasa. QFD menyediakan metode yang tersistematis menentukan kebutuhan konsumen, prioritas dan menerjemahkan ke dalam parameter desain produk/jasa menjamin kepuasan konsumen. HOQ mengkorelasikan keinginan kualitas (keinginan konsumen secara sederhana disebut dengan what's) beraneka makna (how) di mana keinginan konsumen dapat dipuaskan. Menyusun data matrix HOQ penting karena kunci dalam penyusunan isu kualitas, interrelationships dan keberartian relatif antar satu dengan lainnya sehingga membuat kriteria kepuasan konsumen.

\section{METODOLOGI PENELITIAN}

Metodologi yang digunakan dalam penelitian ini adalah survey, yang meliputi pemberian angket, wawancara, dan fokus group. Penelitian dilakukan di jurusan PG PAUD FIP UNJ dari bulan Maret sampai November 2008.

\section{PEMBAHASAN}

\section{Analisa Kinerja Pelayanan PG PAUD Saat Ini}

Kinerja PG PAUD FIP UNJ dalam memberikan layanan saat ini dapat dilihat berdasarkan gap yang terjadi antara ekspektasi dengan persepsi yang dirasakan oleh pelanggan saat ini. Berdasarkan hasil penyebaran kuesioner dapat dijelaskan bahwa tingkat kepentingan menurut persepsi mahasiswa adalah sebagai berikut (1) sistem pengelolaan $(65,62 \%)$, (2) sarana dan prasarana $(62.52 \%)$, (3) sistem informasi $(58,89 \%)$, (4) penelitian $(52,02 \%),(5)$ sumber daya manusia $(51,83 \%)$, (6) lulusan $(49,22 \%)$, (7) kemahasiswaan $(46,41 \%)$, (8) kurikulum $(46,01 \%)$, (9) pendanaan $(44,62 \%)$, (10) kepemimpinan $(40,09 \%)$, dan (11) sistem pembelajaran (35,34\%)

\section{Evaluasi Sistem Pelayanan PG PAUD FIP UNJ}

Gap yang terjadi antara ekspektasi dengan persepsi pelanggan kemudian digunakan sebagai dasar untuk mengidentifikasi masalah pada sistem pelayanan PG PAUD FIP UNJ yang menyebabkan terjadinya gap tersebut. Berdasarkan identifikasi masalah terlihat ada empat permasalahan penyebab utama terjadinya gap antara ekspektasi dengan persepsi pelanggan, antara lain.

1. Buruknya kualitas layanan yang disebabkan rendahnya mutu lulusan (kurikulum, kompetensi umum, budaya akademik, dan infrastruktur), kualitas dan kuantitas variabilitas penelitian, dan rendahnya model pengabdian masyarakat.

2. Rendahnya kualitas SDM, hal ini diakibatkan karena masih rendahnya keahlian dosen dan tenaga kependidikan, rendahnya keterampilan tenaga administrasi, rendahnya kualitas mahasiswa, dan minimnya peran serta alumni.

3. Kurang baiknya pencitraan publik PG PAUD FIP UNJ, diakibatkan oleh minimnya kemitraan dan komitmen melaksanakan program kerjasama, minimnya akses pendidikan yang bermutu rendah, sempitnya kualitas publikasi karya ilmiah, dan masih kurangnya layanan terhadap mahasiswa.

4. Belum optimalnya tata kelola di lingkungan PG PAUD FIP UNJ menyebabkan diperlukannya reformasi birokrasi, belum adanya LPjm (Lembaga Penjamin Mutu) di jurusan, dan minimnya penggunaan sistem informasi dalam manajemen administrasi.

Keempat permasalahan juga diakibatkan oleh kurangnya komitmen dari pihak manajemen sehingga permasalahan di atas dianggap hal yang biasa.

\section{Pembuatan Matriks House of Quality (HOQ) Customer Needs and Benefits}

Bagian ini adalah yang pertama dibuat dalam menyusun matrik HOQ 1. Custmer Needs and Benefits adalah keinginan dan kebutuhan konsumen yang diperoleh dari kuesioner pendahuluan yang kemudian dikelompokkan sehingga terbentuk atribut layanan pendidikan. 
Tabel 1. Pengelompokkan VOC

Berdasarkan Dimensi Kualitas

\begin{tabular}{|c|c|c|}
\hline No & $\begin{array}{l}\text { Dimensi } \\
\text { kualitas } \\
\text { Jasa }\end{array}$ & Voice of Custumer \\
\hline \multirow[t]{16}{*}{1} & \multirow[t]{16}{*}{ Tangibel } & $\begin{array}{l}\text { Sosialisasi rencana strategis PG } \\
\text { PAUD FIP UNJ }\end{array}$ \\
\hline & & $\begin{array}{l}\text { Mahasiswa mengetahui tentang } \\
\text { recana strategis lembaga, visi, misi } \\
\text { dan tujuan PG PAUD FIP UNJ } \\
\text { yang dipublikasikan }\end{array}$ \\
\hline & & Sistem monitoring dan evaluasi \\
\hline & & $\begin{array}{l}\text { Prestasi dalam kegiatan karya } \\
\text { ilmiah }\end{array}$ \\
\hline & & $\begin{array}{l}\text { Dosen berpendidikan minimal } \\
\text { magister (S2) }\end{array}$ \\
\hline & & $\begin{array}{l}\text { Kesenjangan kurikulum dengan } \\
\text { dunia kerja diatasi dengan } \\
\text { menerima input dari dunia kerja } \\
\text { dan alumni (stakeholders) }\end{array}$ \\
\hline & & $\begin{array}{l}\text { Ketersediaan tempat ibadah, air } \\
\text { dan fasilitas MCK yang memadai }\end{array}$ \\
\hline & & $\begin{array}{l}\text { Kelengkapan sarana belajar } \\
\text { mengajar (white board, LCD,dll) }\end{array}$ \\
\hline & & $\begin{array}{l}\text { Standar Operasional Prosedur } \\
\text { (SOP) penggunaan sarana dan } \\
\text { prasaranan di lingkungan PG } \\
\text { PAUD FIP UNJ }\end{array}$ \\
\hline & & $\begin{array}{l}\text { Kemampuan Jurusan memperoleh } \\
\text { dana dari luar institusi }\end{array}$ \\
\hline & & $\begin{array}{lr}\text { Informasi dan } & \text { prosedur } \\
\text { penyusunan/perbaikan } & \text { KRS, } \\
\text { KHS, PKL, PPL dan TA/Skripsi } \\
\text { melalui buku pedoman yang } \\
\text { tersedia }\end{array}$ \\
\hline & & $\begin{array}{l}\text { Standarisasi mutu pembelajaran } \\
\text { diterapkan sesuai dengan } \\
\text { peraturan, seperti } 2 \text { SKS minimal } \\
14 \text { tatap muka }\end{array}$ \\
\hline & & $\begin{array}{l}\text { Dosen memberikan diktat, } \\
\text { Handout dalam perkuliahan }\end{array}$ \\
\hline & & $\begin{array}{l}\text { Fasilitas teknologi } \\
\text { informasi/komputer dilengkapi } \\
\text { dengan jaringan internet yang } \\
\text { dapat melayani kebutuhan }\end{array}$ \\
\hline & & $\begin{array}{l}\text { Lulus dengan tepat waktu (maks.5 } \\
\text { tahun) }\end{array}$ \\
\hline & & $\begin{array}{l}\text { Lulusan PG PAUD } \\
\text { memiliki TOEFL }>=400\end{array}$ \\
\hline \multirow[t]{2}{*}{2} & \multirow[t]{2}{*}{ Reability } & $\begin{array}{l}\text { Keterlibatan mahasiswa dalam } \\
\text { proses pemilihan pimpinan di } \\
\text { lingkungan PG PAUD FIP UNJ }\end{array}$ \\
\hline & & $\begin{array}{l}\text { Mekanisme pemilihan mahasiswa } \\
\text { berprestasi dan penghargaan } \\
\text { terhadap mahasiswa berprestasi }\end{array}$ \\
\hline
\end{tabular}

\begin{tabular}{|c|c|c|}
\hline No & $\begin{array}{l}\text { Dimensi } \\
\text { kualitas } \\
\text { Jasa }\end{array}$ & Voice of Custumer \\
\hline & & $\begin{array}{l}\text { Dosen yang profesional dan } \\
\text { kompeten } \\
\text { spesifikasi mata kuliah yang } \\
\text { diajarkan }\end{array}$ \\
\hline & & $\begin{array}{l}\text { Rasio jumlah dosen terhadap } \\
\text { mahasiswa }\end{array}$ \\
\hline & & $\begin{array}{l}\text { Perubahan kurikulum dilakukan } \\
\text { secara berkesinambungan dengan } \\
\text { melakukan workshop }\end{array}$ \\
\hline & & $\begin{array}{l}\text { Bahan pembelajaran mengikuti } \\
\text { perkembangan IPTEKS }\end{array}$ \\
\hline & & Materi praktek yang memadai \\
\hline & & $\begin{array}{lr}\text { Lembaga } & \text { menyediakan } \\
\text { laboratorium } & \text { dan } \\
\text { perlengkapannya } & \text { sesuai } \\
\text { kebutuhan } & \text { dengan }\end{array}$ \\
\hline & & $\begin{array}{l}\text { Penggunaan ruang } \\
\text { kuliah/laboratorium sesui dengan } \\
\text { jadwal }\end{array}$ \\
\hline & & $\begin{array}{l}\text { Ketersediaan buku/jurnal dan } \\
\text { lain-lain di perpustakaan dalam } \\
\text { menunjang perkuliahan yang up- } \\
\text { to date }\end{array}$ \\
\hline & & $\begin{array}{ll}\text { Pembelajaran } & \text { berlangsung } \\
\text { interaktif } & \end{array}$ \\
\hline & & $\begin{array}{l}\text { Kesesuaian antara informasi yang } \\
\text { diberikan dengan realisasi }\end{array}$ \\
\hline & & $\begin{array}{l}\text { Hasil penelitian/Skripsi/TA dapat } \\
\text { bermanfaat bagi masyarakat dan } \\
\text { industri }\end{array}$ \\
\hline \multirow[t]{5}{*}{3} & \multirow[t]{5}{*}{$\begin{array}{l}\text { Responsiv } \\
\text { enes }\end{array}$} & $\begin{array}{lllr}\begin{array}{l}\text { Peranan } \\
\text { aspirasi, }\end{array} & \text { BEMJ } & \begin{array}{l}\text { menyalurkan } \\
\text { mahasiswa }\end{array} & \text { dan bakat } \\
\text { mahas } & & \\
\end{array}$ \\
\hline & & $\begin{array}{lr}\text { Kenyamanan } & \text { ruang } \\
\text { kuliah/laboratorium } & \end{array}$ \\
\hline & & $\begin{array}{l}\text { Sistem monitoring dan evaluasi } \\
\text { pendanaan yang transparan }\end{array}$ \\
\hline & & $\begin{array}{l}\text { Dosen pembimbing responsif } \\
\text { memberikan nasehat perkuliahan }\end{array}$ \\
\hline & & $\begin{array}{l}\text { Mahasiswa } \\
\text { bimbingan karir dan informasi } \\
\text { kerja }\end{array}$ \\
\hline \multirow[t]{5}{*}{4} & \multirow[t]{5}{*}{ Assurance } & $\begin{array}{l}\text { Mekanisme pemilihan pimpinan } \\
\text { di lingkungan PG PAUD FIP UNJ } \\
\text { (Ka.Jur, Ka.Prog, Ka. Lab dan lain- } \\
\text { lain) berdasarkan kepatutan dan } \\
\text { kepantasan }\end{array}$ \\
\hline & & $\begin{array}{l}\text { Lembaga memberikan kesempatan } \\
\text { mahasiswa berkembang dengan } \\
\text { optimal }\end{array}$ \\
\hline & & $\begin{array}{l}\text { Sistem penerimaan mahasiswa } \\
\text { baru yang selektif }\end{array}$ \\
\hline & & $\begin{array}{l}\text { Kesesuaian kurikulum dengan } \\
\text { tuntutan dunia kerja }\end{array}$ \\
\hline & & $\begin{array}{l}\text { Penggunaan anggaran untuk } \\
\text { pengadaan peralatan/bahan } \\
\text { untuk praktekum memiliki porsi } \\
\text { yang lebih banyak }\end{array}$ \\
\hline
\end{tabular}




\begin{tabular}{|c|c|c|}
\hline No & $\begin{array}{c}\text { Dimensi } \\
\text { kualitas } \\
\text { Jasa }\end{array}$ & Voice of Custumer \\
\hline & & $\begin{array}{l}\text { Penggunaan anggaran untuk } \\
\text { pemeliharaan sarana \& prasarana }\end{array}$ \\
\hline & & $\begin{array}{l}\text { Kesesuaian materi kuliah dan } \\
\text { penilaian sesuai dengan deskripsi } \\
\text { mata kuliah dan SAP yang } \\
\text { disampaikan }\end{array}$ \\
\hline & & $\begin{array}{l}\text { Pemberian nilai yang obyektif oleh } \\
\text { dosen }\end{array}$ \\
\hline & & $\begin{array}{l}\text { Kesesuaian pekerjaan dengan } \\
\text { latarbelakang pendidikan }\end{array}$ \\
\hline & & $\begin{array}{l}\text { Setelah lulus mahasiswa dapat } \\
\text { berwirausaha }\end{array}$ \\
\hline \multirow[t]{4}{*}{5} & \multirow[t]{4}{*}{ Empathy } & $\begin{array}{l}\text { Dosen dan karyawan responsif } \\
\text { terhadap kebutuhan mahasiswa }\end{array}$ \\
\hline & & $\begin{array}{l}\text { Karyawan ramah dan profesional } \\
\text { dalam melayani mahasiswa }\end{array}$ \\
\hline & & Kode etik dosen \\
\hline & & $\begin{array}{l}\text { Layanan informasi diberikan } \\
\text { dengan ramah }\end{array}$ \\
\hline
\end{tabular}

\section{Planning Matriks}

Planning matriks merupakan bagian matriks HOQ yang memberikan informasi secara kuantitatif yang dibutuhkan mahasiswa PG PAUD FIP UNJ. Bagian ini menghitung bobot secara kuantitatif atas beberapa hal, yaitu.

Tabel 2. Importance to Costumer, Custumer Satification Performance, Goal, ID, Raw Weight dan Normalized Raw Weight

\begin{tabular}{|l|l|l|l|l|l|l|l|l|}
\hline No & \multicolumn{1}{|c|}{ Pernyataan } & IC & CFP & Goal & ID & IW & RW & $\begin{array}{c}\text { NR } \\
\text { W }\end{array}$ \\
\hline K01 & $\begin{array}{l}\text { Mekanisme pemilihan } \\
\text { pimpinan di lingkungan } \\
\text { PG PAUD FIP UNJ } \\
\text { (Ka.Jur, Ka.Prog, Ka. Lab } \\
\text { dan lain-lain) } \\
\text { berdasarkan kepatutan } \\
\text { dan kepantasan }\end{array}$ & 4.008 & 3.524 & 4 & 1.476 & 7.422 & 5.916 & 0.012 \\
\hline K02 & $\begin{array}{l}\text { Sosialisasi rencana } \\
\text { strategis PG PAUD FIP } \\
\text { UNJ }\end{array}$ & 4.111 & 3.190 & 4 & 1.810 & 75.991 & 7.439 & 0.015 \\
\hline K03 & $\begin{array}{l}\text { Mahasiswa Mengetahui } \\
\text { tentang rencana strategis } \\
\text { lembaga, visi,misi dan } \\
\text { tujuan PG PAUD FIP } \\
\text { UNJyang dipublikasikan }\end{array}$ & 4.079 & 3.238 & 4 & 1.762 & 12.881 & 7.187 & 0.015 \\
\hline K04 & $\begin{array}{l}\text { Keterlibatan mahasiswa } \\
\text { dalam proses pemilihan } \\
\text { pimpinan di lingkungan } \\
\text { PG PAUD FIP UNJ }\end{array}$ & 4.294 & 3.373 & 3 & 0.627 & 2.412 & 2.692 & 0.005 \\
\hline K05 & $\begin{array}{l}\text { Sistem monitoring dan } \\
\text { evaluasi }\end{array}$ & 4.143 & 3.246 & 4 & 1.754 & 26.045 & 7.266 & 0.015 \\
\hline
\end{tabular}

\begin{tabular}{|c|c|c|c|c|c|c|c|c|}
\hline No & Pernyataan & IC & CFP & Goal & ID & IW & $R W$ & $\begin{array}{l}N R \\
W\end{array}$ \\
\hline K06 & $\begin{array}{l}\text { Mekanisme pemilihan } \\
\text { mahasiswa berprestasi } \\
\text { dan penghargaan } \\
\text { terhadap mahasiswa } \\
\text { berprestasi } \\
\end{array}$ & 4.246 & 2.881 & 5 & 3.119 & 37.974 & 13.244 & 0.027 \\
\hline K07 & \begin{tabular}{|l|} 
Peranan BEMJ \\
menyalurkan aspirasi, \\
minat dan bakat \\
mahasiswa \\
\end{tabular} & 4.190 & 3.032 & 5 & 2.968 & 57.957 & 12.438 & 0.025 \\
\hline K08 & $\begin{array}{l}\begin{array}{l}\text { Prestasi dalam kegiatan } \\
\text { karya ilmiah }\end{array} \\
\end{array}$ & 3.984 & 3.000 & 4 & 2.000 & 67.116 & 7.968 & 0.016 \\
\hline K09 & $\begin{array}{l}\text { Lembaga memberikan } \\
\text { kesempatan mahasiswa } \\
\text { berkembang dengan } \\
\text { optimal } \\
\end{array}$ & 4.325 & 3.270 & 5 & 2.730 & 232.79 & 11.809 & 0.024 \\
\hline K10 & $\begin{array}{l}\text { Dosen berpendidikan } \\
\text { minimal magister (S2) }\end{array}$ & 4.421 & 3.627 & 5 & 2.373 & 30.080 & 10.490 & 0.021 \\
\hline K11 & \begin{tabular}{|l} 
Dosen yang profesional \\
dan kompeten sesuai \\
dengan spesifikasi mata \\
kuliah yang diajarkan \\
\end{tabular} & 4.571 & 3.540 & 5 & 2.460 & 286.21 & 11.247 & 0.023 \\
\hline K12 & $\begin{array}{l}\text { Dosen dan karyawan } \\
\text { responsif terhadap } \\
\text { kebutuhan mahasiswa }\end{array}$ & 4.444 & 3.183 & 5 & 2.817 & 67.323 & 12.522 & 0.025 \\
\hline K13 & $\begin{array}{l}\text { Karyawan ramah dan } \\
\text { profesional dalam } \\
\text { melayani mahasiswa }\end{array}$ & 4.500 & 3.230 & 4 & 1.770 & 17.127 & 7.964 & 0.016 \\
\hline K14 & \begin{tabular}{|l|} 
Rasio jumlah dosen \\
terhadap mahasiswa \\
\end{tabular} & 4.278 & 3.192 & 4 & 1.808 & 45.740 & 7.734 & 0.016 \\
\hline K15 & $\begin{array}{l}\text { Sistem penenerimaan } \\
\text { mahasiswa baru yang } \\
\text { selektif } \\
\end{array}$ & 4.325 & 3.357 & 4 & 1.643 & 11.461 & 7.106 & 0.014 \\
\hline K16 & Kode etik dosen & 4.437 & 3.492 & 4 & 1.508 & 44.360 & 6.690 & 0.014 \\
\hline K17 & $\begin{array}{l}\text { Perubahan kurikulum } \\
\text { berkesinambungan } \\
\text { dengan melakukan } \\
\text { workshop }\end{array}$ & 4.095 & 3.349 & 4 & 1.651 & 88.442 & 6.760 & 0.014 \\
\hline K18 & $\begin{array}{l}\text { Kesesuaian kurikulum } \\
\text { dengan tuntutan dunia } \\
\text { kerja }\end{array}$ & 4.540 & 3.429 & 4 & 1.571 & 106.11 & 7.134 & 0.014 \\
\hline K19 & $\begin{array}{l}\text { Bahan pembelajaran } \\
\text { mengikuti } \\
\text { perkembangan IPTEKS } \\
\end{array}$ & 4.500 & 3.294 & 5 & 2.706 & 266.27 & 12.179 & 0.025 \\
\hline K20 & $\begin{array}{l}\text { Gap kurikulum diatasi } \\
\text { dengan menerima input } \\
\text { dari alumni dan } \\
\text { stakeholders } \\
\end{array}$ & 4.214 & 3.206 & 4 & 1.794 & 113.79 & 7.559 & 0.015 \\
\hline K21 & \begin{tabular}{|l} 
Keterlibatan Stake Holders \\
memberikan input \\
penyempurnaan \\
kurikulum \\
\end{tabular} & 4.397 & 3.056 & 5 & 2.944 & 120.64 & 12.946 & 0.026 \\
\hline K22 & \begin{tabular}{|l|} 
Ketersediaan \\
laboratorium dan \\
perlengkapannya sesuai \\
dengan kebutuhan \\
\end{tabular} & 4.619 & 2.905 & 5 & 3.095 & 35.871 & 14.297 & 0.029 \\
\hline K23 & $\begin{array}{l}\text { Ketercukupan Ruangan } \\
\text { Kuliah mahasiswa }\end{array}$ & 4.222 & 2.976 & 5 & 3.024 & 20.592 & 12.767 & 0.026 \\
\hline K24 & $\begin{array}{l}\text { Ketersediaan tempat } \\
\text { ibadah, air dan fasilitas } \\
\text { MCK yang memadai }\end{array}$ & 4.643 & 2.571 & 4 & 2.429 & 38.393 & 11.276 & 0.023 \\
\hline K25 & $\begin{array}{l}\text { Penggunaan ruang } \\
\text { kuliah/laboratorium } \\
\text { sesui dengan jadwal }\end{array}$ & 4.516 & 2.730 & 4 & 2.270 & 34.903 & 10.250 & 0.021 \\
\hline
\end{tabular}




\begin{tabular}{|c|c|c|c|c|c|c|c|c|}
\hline No & Pernyataan & IC & CFP & Goal & ID & IW & $R W$ & $\begin{array}{l}\text { NR } \\
W\end{array}$ \\
\hline $\mathrm{K} 26$ & $\begin{array}{l}\text { Pengounaan ruang } \\
\text { kuliah sesuai jadwal }\end{array}$ & 4.706 & 2.468 & 4 & 2.532 & 21.354 & 11.915 & 0.024 \\
\hline K27 & $\begin{array}{l}\text { Kenyamanan ruang } \\
\text { kuliah/laboratorium }\end{array}$ & 4.643 & 2.619 & 5 & 3.381 & 92.833 & 15.697 & 0.032 \\
\hline K28 & $\begin{array}{l}\text { Kelengkapan sarana } \\
\text { belajar mengajar (white } \\
\text { board, LCD,dll) } \\
\end{array}$ & 4.500 & 3.032 & 5 & 2.968 & 67.025 & 13.357 & 0.027 \\
\hline $\mathrm{K} 29$ & \begin{tabular}{|l|} 
Ketersediaan \\
buku/jurnal dan lain-lain \\
menunjang perkuliahan \\
yg up-to date \\
\end{tabular} & 4.349 & 2.976 & 5 & 3.024 & 209.77 & 13.152 & 0.027 \\
\hline K30 & \begin{tabular}{|l|} 
SOP penggunaan sarana \\
dan prasaranann di \\
lingkungan PG PAUD \\
FIP UNJ \\
\end{tabular} & 4.317 & 2.816 & 4 & 2.184 & 69.284 & 9.429 & 0.019 \\
\hline K31 & $\begin{array}{l}\text { Penggunaan anggaran } \\
\text { untuk pengadaan } \\
\text { peralatan/bahan untuk } \\
\text { praktekum } \\
\end{array}$ & 4.325 & 2.808 & 4 & 2.192 & 78.161 & 9.481 & 0.019 \\
\hline K32 & $\begin{array}{l}\text { Penggunaan anggaran } \\
\text { untuk pemeliharaan } \\
\text { sarana \& prasarana }\end{array}$ & 4.262 & 2.840 & 4 & 2.160 & 64.341 & 9.206 & 0.019 \\
\hline K33 & \begin{tabular}{|l|} 
Sistem monitoring dan \\
evaluasi pendanaan yang \\
transparan
\end{tabular} & 4.135 & 3.008 & 4 & 1.992 & 36.903 & 8.237 & 0.017 \\
\hline K34 & $\begin{array}{l}\text { Kemampuan Jurusan } \\
\text { memperoleh dana dari } \\
\text { luar institusi } \\
\end{array}$ & 4.508 & 3.136 & 5 & 2.864 & 164.28 & 12.911 & 0.026 \\
\hline K35 & \begin{tabular}{|l|} 
Informasi dan prosedur \\
penyusunan/perbaikan \\
KRS, KHS, PPL dan \\
TA/Skripsi melalui buku \\
pedoman
\end{tabular} & 4.484 & 3.064 & 5 & 2.936 & 77.860 & 13.165 & 0.027 \\
\hline K36 & $\begin{array}{l}\text { Dosen pembimbing } \\
\text { responsif dalam } \\
\text { memberikan nasehat } \\
\text { perkuliahan } \\
\end{array}$ & 4.587 & 3.176 & 5 & 2.824 & 116.08 & 12.955 & 0.026 \\
\hline K37 & $\begin{array}{l}\text { Standarisasi mutu } \\
\text { pembelajaran diterapkan } \\
\text { sesuai dengan peraturan }\end{array}$ & 4.286 & 3.360 & 5 & 2.640 & 64.885 & 11.314 & 0.023 \\
\hline K38 & \begin{tabular}{|l} 
Pembelajaran \\
berlangsung interaktif
\end{tabular} & 4.413 & 3.408 & 4 & 1.592 & 79.315 & 7.025 & 0.014 \\
\hline K39 & $\begin{array}{l}\text { Kesesuaian materi } \\
\text { perkuliahan dengan } \\
\text { deskripsi matakuliah } \\
\end{array}$ & 4.357 & 3.296 & 4 & 1.704 & 106.44 & 7.425 & 0.015 \\
\hline K40 & $\begin{array}{l}\text { Pemberian nilai yang } \\
\text { obyektif oleh dosen }\end{array}$ & 4.460 & 3.312 & 4 & 1.688 & 40.479 & 7.529 & 0.015 \\
\hline K41 & \begin{tabular}{|l} 
Dosen memberikan \\
diktat, Handout dalam \\
perkuliahan \\
\end{tabular} & 4.476 & 3.576 & 5 & 2.424 & 124.45 & 10.850 & 0.022 \\
\hline K42 & \begin{tabular}{|l} 
Fasilitas teknologi \\
informasi/computer \\
dilengkapi dengan \\
jaringan internet \\
\end{tabular} & 4.556 & 3.016 & 5 & 2.984 & 126.68 & 13.594 & 0.028 \\
\hline K43 & $\begin{array}{l}\text { Kesesuaian antara } \\
\text { informasi yang diberikan } \\
\text { dengan realisasi } \\
\end{array}$ & 4.325 & 3.200 & 5 & 2.800 & 41.239 & 12.111 & 0.025 \\
\hline
\end{tabular}

\begin{tabular}{|l|l|c|c|c|c|c|c|c|}
\hline No & \multicolumn{1}{|c|}{ Pernyataan } & IC & CFP & Goal & ID & IW & RW & $\begin{array}{c}\text { NR } \\
\text { W }\end{array}$ \\
\hline K44 & $\begin{array}{l}\text { Layanan informasi } \\
\text { diberikan dengan ramah }\end{array}$ & 4.500 & 3.328 & 5 & 2.672 & 49.561 & 12.024 & 0.024 \\
\hline K45 & $\begin{array}{l}\text { Lulus dengan tepat } \\
\text { waktu (maks.5 tahun) }\end{array}$ & 4.373 & 3.376 & 4 & 1.624 & 15.273 & 7.102 & 0.014 \\
\hline K46 & $\begin{array}{l}\text { Lulusan PG PAUD FIP } \\
\text { UNJ memiliki } \\
\text { TOEFL>=400 }\end{array}$ & 4.286 & 3.360 & 4 & 1.640 & 86.912 & 7.029 & 0.014 \\
\hline K47 & $\begin{array}{l}\text { Mahasiswa memperoleh } \\
\text { bimbingan karir dan } \\
\text { informasi kerja }\end{array}$ & 4.452 & 3.320 & 4 & 1.680 & 57.642 & 7.480 & 0.015 \\
\hline K48 & $\begin{array}{l}\text { Kesesuaian pekerjaan } \\
\text { dengan latar belakang } \\
\text { pendidikan }\end{array}$ & 4.349 & 3.464 & 5 & 2.536 & 122.55 & 11.030 & 0.022 \\
\hline K49 & $\begin{array}{l}\text { Setelah lulus mahasiswa } \\
\text { dapat berwirausaha }\end{array}$ & 4.444 & 3.448 & 4 & 1.552 & 80.350 & 6.898 & 0.014 \\
\hline K50 & $\begin{array}{l}\text { Hasil } \\
\text { penelitian/Skripsi/TA } \\
\text { dapat bermanfaat bagi } \\
\text { masyarakat dan industri }\end{array}$ & 4.548 & 3.488 & 4 & 1.512 & 60.381 & 6.876 & 0.014 \\
\hline
\end{tabular}

\section{Technical Response}

Technical Response (TR) merupakan informasi teknis yang digunakan untuk mendeskripsikan kinerja atas jasa yang disediakannya berdasarkan atribut layanan kebutuhan pelanggan (Voice of Costumers) yang kemudian ditranslasikan ke dalam gambaran bagaimana atribut layanan tersebut akan dikembangkan (Voice of Deploper). Bidang jasa ukuran kinerja dapat dilakukan dengan pendekatan proses pelayanan jasa tersebut dari awal hingga akhir sampai ke pelanggan. Proses dalam sistem pelayanan pendidikan di PG PAUD FIP UNJ

Tabel 3. Perhitungan Technical Matrix

\begin{tabular}{|l|l|l|}
\hline \multicolumn{1}{|c|}{ TECHNICAL RESPONSE } & RW & NRW \\
\hline $\begin{array}{l}\text { Menerapkan model-model } \\
\text { pembelajaran AUD di lab internal } \\
\text { dan eksternal }\end{array}$ & 95 & $4.417 \%$ \\
\hline $\begin{array}{l}\text { Workshop pengembangan silabus } \\
\text { perkuliahan }\end{array}$ & 91 & $4.231 \%$ \\
\hline $\begin{array}{l}\text { Menambah sarana dan prasarana } \\
\text { yang dibutuhkan untuk } \\
\text { pengembangan kurikulum }\end{array}$ & 90 & $4.184 \%$ \\
\hline $\begin{array}{l}\text { Melakukan } \\
\text { seminar/pelatihan/workshop } \\
\text { tentang pendidikan anak usia dini } \\
\text { yang melibatkan narasumber dari } \\
\text { dalam dan luar negeri }\end{array}$ & 86 & $3.998 \%$ \\
\hline $\begin{array}{l}\text { Mengirimkan dosen untuk } \\
\text { mengikuti seminar, pelatihan dan } \\
\text { workshop pembelajaran anak usia } \\
\text { dini }\end{array}$ & 84 & $3.905 \%$ \\
\hline
\end{tabular}




\begin{tabular}{|c|c|c|}
\hline TECHNICAL RESPONSE & RW & NRW \\
\hline $\begin{array}{l}\text { Sosialisasi dan revitalisasi } \\
\text { laboratorium PAUD }\end{array}$ & 82 & $3.812 \%$ \\
\hline $\begin{array}{l}\text { Memperbaiki silabi sesuai dengan } \\
\text { struktur kurikulum yang direvisi }\end{array}$ & 79 & $3.673 \%$ \\
\hline $\begin{array}{l}\text { Pembelian jenis dan jumlah literatur } \\
\text { perkuliahan (buku dan film) }\end{array}$ & 79 & $3.673 \%$ \\
\hline $\begin{array}{l}\text { Merintis beragam bentuk layanan } \\
\text { pendidikan anak usia dini di } \\
\text { masyarakat }\end{array}$ & 74 & $3.440 \%$ \\
\hline $\begin{array}{l}\text { Mengajukan permintaan tenaga } \\
\text { volunteer anak usia dini pada } \\
\text { lembaga dalam dan luar negeri }\end{array}$ & 74 & $3.440 \%$ \\
\hline $\begin{array}{l}\text { Mengirimkan dosen untuk } \\
\text { mengikuti international short course } \\
\text { program }\end{array}$ & 72 & $3.347 \%$ \\
\hline $\begin{array}{l}\text { Menyusun dan mengoptimalkan in } \\
\text { put data dari SDM dalam rangka } \\
\text { mencapai nilai akreditasi A } \\
\text { (Pengisian Borang) }\end{array}$ & 66 & $3.068 \%$ \\
\hline $\begin{array}{l}\text { Memantau administrasi akademik } \\
\text { mahasiswa yang akan } \\
\text { menyelesaikan studi }\end{array}$ & 62 & $2.882 \%$ \\
\hline $\begin{array}{l}\text { Lokakarya keilmuan PAUD yang } \\
\text { melibatkan para pakar pendidikan, } \\
\text { psikolog, neurolog dan stake holder }\end{array}$ & 58 & $2.696 \%$ \\
\hline $\begin{array}{l}\text { Pembelian media pembelajaran } \\
\text { (LCD Projector, Laptop/ Note book, } \\
\text { DVD Player, Televisi, Tape } \\
\text { Recorder) }\end{array}$ & 56 & $2.603 \%$ \\
\hline $\begin{array}{l}\text { Mengirimkan para dosen S1 untuk } \\
\text { melakukan studi lanjut baik dalam } \\
\text { maupun luar negeri (S2 dan S3) }\end{array}$ & 55 & $2.557 \%$ \\
\hline $\begin{array}{l}\text { Workshop pelatihan pembelajaran } \\
\text { berbantuan komputer dan internet } \\
\text { dalam perkuliahan }\end{array}$ & 55 & $2.557 \%$ \\
\hline $\begin{array}{l}\text { Menambah SDM pada Tim } \\
\text { Pengembang Kurikulum melibatkan } \\
\text { neurology }\end{array}$ & 49 & $2.278 \%$ \\
\hline $\begin{array}{l}\text { Merancang jadwal penyelesaian } \\
\text { studi di awal semester }\end{array}$ & 48 & $2.232 \%$ \\
\hline Menyusun database perpustakaan & 46 & $2.139 \%$ \\
\hline $\begin{array}{l}\text { Merevisi pedoman teknis } \\
\text { pelaksanaan kegiatan PPL dan } \\
\text { penilaiannya }\end{array}$ & 45 & $2.092 \%$ \\
\hline $\begin{array}{l}\text { Evaluasi penyelenggaraan } \\
\text { laboratorium PAUD }\end{array}$ & 45 & $2.092 \%$ \\
\hline $\begin{array}{l}\text { Mengatur distribusi pembimbing } \\
\text { skripsi/kompre sesuai spesifikasi } \\
\text { keahlian. }\end{array}$ & 44 & $2.046 \%$ \\
\hline $\begin{array}{l}\text { Mengadakan kegiatan bakti sosial di } \\
\text { lembaga PAUD pra-sejahtera }\end{array}$ & 43 & $1.999 \%$ \\
\hline $\begin{array}{l}\text { Peningkatan prosentasi kualitas dan } \\
\text { kuantitas mahasiswa penerima } \\
\text { beasiswa }\end{array}$ & 43 & $1.999 \%$ \\
\hline
\end{tabular}

\begin{tabular}{|l|l|l|}
\hline \multicolumn{1}{|c|}{ TECHNICAL RESPONSE } & RW & NRW \\
\hline $\begin{array}{l}\text { Mengikutsertakan para dosen dan } \\
\text { mahasiswa dalam progran pelatihan } \\
\text { dan pembinaan penulisan karya } \\
\text { ilmiah }\end{array}$ & 42 & $1.953 \%$ \\
\hline $\begin{array}{l}\text { Mengadakan kerjasama pengadaan } \\
\text { dosen pembimbing }\end{array}$ & 39 & $1.813 \%$ \\
\hline $\begin{array}{l}\text { Mengadakan koordinasi kegiatan } \\
\text { PPL antara Jurusan dengan } \\
\text { stakeholder }\end{array}$ & 39 & $1.813 \%$ \\
\hline $\begin{array}{l}\text { Studi banding ke perguruan tinggi } \\
\text { luar negeri }\end{array}$ & 37 & $1.720 \%$ \\
\hline $\begin{array}{l}\text { Pelatihan bahasa Inggris untuk } \\
\text { dosen }\end{array}$ & 37 & $1.720 \%$ \\
\hline $\begin{array}{l}\text { Melaksanakan gerakan "sumbang } \\
\text { buku" dari mahasiswa baru dan } \\
\text { mahasiswa yang akan lulus. }\end{array}$ & 37 & $1.720 \%$ \\
\hline $\begin{array}{l}\text { Menjalin kerjasama dengan lembaga } \\
\text { swadaya masyarakat yang } \\
\text { berkonsentrasi pada } \\
\text { penyelenggaraan PAUD }\end{array}$ & 37 & $1.720 \%$ \\
\hline $\begin{array}{l}\text { Mengadakan konsolidasi dengan } \\
\text { prodi PAUD pasca sarjana (S2-S3) } \\
\text { dalam rangka integrasi pengeloaan }\end{array}$ & 35 & $1.627 \%$ \\
\hline $\begin{array}{l}\text { Mengadakan seminar/workshop } \\
\text { untuk mempublikasikan karya } \\
\text { inovatif. }\end{array}$ & 34 & $1.581 \%$ \\
\hline $\begin{array}{l}\text { Memelihara jalinan kerjasama } \\
\text { dengan departemen pendidikan } \\
\text { nasional (direktorat PAUD, } \\
\text { direktorat Dikmas, dll) }\end{array}$ & 34 & $1.581 \%$ \\
\hline $\begin{array}{l}\text { Beautifikasi ruangan belajar } \\
\text { (penyediaan AC dan pengecatan) }\end{array}$ & 32 & $1.488 \%$ \\
\hline $\begin{array}{l}\text { Terlibat secara aktif di dalam } \\
\text { organisasi yang berkecimpung di } \\
\text { dunia PAUD (Himpaudi, Forum } \\
\text { PADU, Konsorsium PAUD, } \\
\text { ISPAUDI) }\end{array}$ & 32 & $1.488 \%$ \\
\hline $\begin{array}{l}\text { Melakukan kegiatan penyuluhan } \\
\text { tentang pola asuh kepada } \\
\text { masyarakat melalui kegiatan KKN } \\
\text { (kuliah Kerja Nyata) }\end{array}$ & 31 & $1.441 \%$ \\
\hline $\begin{array}{l}\text { Melakukan konsolidasi dengan } \\
\text { penasehat akademik dan } \\
\text { pembimbing skripsi/kompre setiap } \\
3 \text { bulan sekali }\end{array}$ & 23 & $1.069 \%$ \\
\hline $\begin{array}{l}\text { Penyediaan lemari arsip dan Menata } \\
\text { database kelembagaan }\end{array}$ & 14 & $0.651 \%$ \\
\hline $\begin{array}{l}\text { Peningkatan kemampuan } \\
\text { mahasiswa dalam kepemimpinan } \\
\text { dan manajemen organisasi } \\
\text { kemahasiswaan }\end{array}$ & $0.651 \%$ \\
\hline $\begin{array}{l}\text { Membantu pendirian prodi PAUD di } \\
\text { perguruan tinggi negeri maupun } \\
\text { swasta }\end{array}$ & 13 & $0.604 \%$ \\
\hline TOTAL & $14 \%$ \\
\hline
\end{tabular}




\section{Pembentukan Strategic Vision}

Strategic vison dibentuk berdasarkan peringkat kepentingan relatif yang tertinggi pada Technical Response. Berikut nilai tertinggi TR untuk penilaian relatif terhadap pelanggan yang kiranya menjadi prioritas untuk diperbaiki terutama untuk meningkatkan kualitas layanan pendidikan di PG PAUD FIP UNJ.

Tabel 4: Proses Pembentukan Strategic Vision Element

\begin{tabular}{|c|c|c|c|}
\hline No & $\begin{array}{l}\text { Strategic } \\
\text { Vision } \\
\text { Element }\end{array}$ & $\begin{array}{l}\text { Urutan } \\
\text { Prioritas }\end{array}$ & Technical Response \\
\hline \multirow[t]{8}{*}{1} & \multirow[t]{8}{*}{$\begin{array}{l}\text { Peningkatan } \\
\text { Mutu } \\
\text { Relevansi } \\
\text { dan Daya } \\
\text { Saing }\end{array}$} & 1 & $\begin{array}{l}\text { Menerapkan model-model } \\
\text { pembelajaran AUD di } \\
\text { laboratorium internal dan } \\
\text { eksternal }\end{array}$ \\
\hline & & 2 & $\begin{array}{l}\text { Workshop pengembangan } \\
\text { silabus perkuliahan }\end{array}$ \\
\hline & & 8 & $\begin{array}{l}\text { Pembelian jenis dan jumlah } \\
\text { literatur (buku dan film) }\end{array}$ \\
\hline & & 13 & $\begin{array}{l}\text { Lokakarya keilmuan PAUD } \\
\text { yang melibatkan para } \\
\text { pakar pendidikan, } \\
\text { psikolog, neurolog dan } \\
\text { stake holder }\end{array}$ \\
\hline & & 23 & $\begin{array}{l}\text { Mengikutsertakan para } \\
\text { dosen dan mahasiswa } \\
\text { dalam progran pelatihan } \\
\text { dan pembinaan penulisan } \\
\text { karya ilmiah }\end{array}$ \\
\hline & & 27 & $\begin{array}{lrr}\text { Studi banding } & \text { ke } \\
\text { perguruan tinggi } & \text { luar } \\
\text { negeri } & & \text { yang } \\
\text { menyelenggarakan } & \\
\text { program S1 PAUD } & \\
\end{array}$ \\
\hline & & 29 & $\begin{array}{l}\text { Melaksanakan gerakan } \\
\text { "sumbang buku" dari } \\
\text { mahasiswa baru dan } \\
\text { mahasiswa yang akan lulus }\end{array}$ \\
\hline & & 32 & \begin{tabular}{lr}
\multicolumn{2}{l}{ Menjalin kerjasama dengan } \\
lembaga & swadaya \\
masyarakat & yang \\
berkonsentrasi & pada \\
penyelenggaraan & PAUD \\
\end{tabular} \\
\hline \multirow[t]{2}{*}{2} & \multirow[t]{2}{*}{$\begin{array}{l}\text { Penguatan } \\
\text { Tata Kelola } \\
\text { dan } \\
\text { Akuntabilita } \\
\text { s }\end{array}$} & 3 & $\begin{array}{l}\text { Menambah sarana dan } \\
\text { prasarana yang dibutuhkan } \\
\text { untuk pengembangan } \\
\text { kurikulum }\end{array}$ \\
\hline & & 7 & $\begin{array}{l}\text { Memperbaiki silabi } \\
\text { perkuliahan sesuai dengan } \\
\text { struktur kurikulum yang } \\
\text { direvisi }\end{array}$ \\
\hline
\end{tabular}

\begin{tabular}{|c|c|c|c|}
\hline No & $\begin{array}{l}\text { Strategic } \\
\text { Vision } \\
\text { Element }\end{array}$ & $\begin{array}{l}\text { Urutan } \\
\text { Prioritas }\end{array}$ & Technical Response \\
\hline & & 11 & $\begin{array}{l}\text { Menyusun } \\
\text { mengoptimalkan in put } \\
\text { data dari SDM dalam } \\
\text { rangka mencapai nilai } \\
\text { akreditasi A (Pengisian } \\
\text { Borang) }\end{array}$ \\
\hline & & 12 & \begin{tabular}{ll}
\multicolumn{3}{|l}{ Memantau perkembangan } \\
mhs yang akan \\
menyelesaikan studi
\end{tabular} \\
\hline & & 13 & $\begin{array}{|lr|}\text { Pembelian } & \text { media } \\
\text { pembelajaran } & \text { (LCD } \\
\text { Projector, Laptop/ } & \text { Note } \\
\text { book, DVD Player, Televisi, } & \\
\text { Tape Recorder) } & \\
\end{array}$ \\
\hline & & 16 & $\begin{array}{l}\text { Menambah SDM pada Tim } \\
\text { Pengembang Kurikulum } \\
\text { melibatkan neurolog }\end{array}$ \\
\hline & & 17 & \begin{tabular}{|lrl} 
Merancang jadwal \\
penyelesaian studi di awal \\
semester
\end{tabular} \\
\hline & & 18 & \begin{tabular}{|ll}
$\begin{array}{l}\text { Menyusun } \\
\text { perpustakaan }\end{array}$ & database \\
\end{tabular} \\
\hline & & 19 & $\begin{array}{l}\text { Merevisi pedoman teknis } \\
\text { pelaksanaan kegiatan PPL } \\
\text { dan penilaiannya }\end{array}$ \\
\hline & & 20 & $\begin{array}{l}\text { Evaluasi penyelenggaraan } \\
\text { laboratorium PAUD }\end{array}$ \\
\hline & & 21 & \begin{tabular}{|lr} 
Mengatur & distribusi \\
pembimbing & \\
skripsi/kompre & sesuai \\
dengan & spesifikasi \\
keahlian. & \\
\end{tabular} \\
\hline & & 24 & 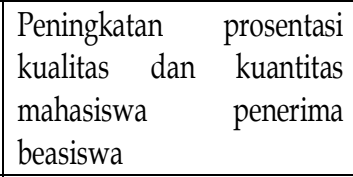 \\
\hline & & 25 & $\begin{array}{|lr|}\text { Mengadakan } & \text { kerjasama } \\
\text { dengan jurusan lain } & \text { untuk } \\
\text { pengadaan } & \text { dosen } \\
\text { pembimbing } & \\
\end{array}$ \\
\hline & & 28 & $\begin{array}{l}\text { Pelatihan bahasa Inggris } \\
\text { untuk dosen }\end{array}$ \\
\hline & & 34 & $\begin{array}{l}\text { Mengadakan konsolidasi } \\
\text { dengan prodi PAUD pasca } \\
\text { sarjana (S2-S3) dalam }\end{array}$ \\
\hline 3 & \begin{tabular}{|l} 
Sumber \\
Daya \\
Manusia
\end{tabular} & 4 & $\begin{array}{l}\text { Melakukan } \\
\text { seminar/pelatihan/worksh } \\
\text { op pendidikan anak usia } \\
\text { dini yang melibatkan nara } \\
\text { sumber dalam dan luar } \\
\text { negeri }\end{array}$ \\
\hline
\end{tabular}




\begin{tabular}{|c|c|c|c|}
\hline No & $\begin{array}{l}\text { Strategic } \\
\text { Vision } \\
\text { Element }\end{array}$ & $\begin{array}{l}\text { Urutan } \\
\text { Prioritas }\end{array}$ & Technical Response \\
\hline & & 5 & $\begin{array}{l}\text { Mengirimkan dosen untuk } \\
\text { mengikuti seminar, } \\
\text { pelatihan dan workshop } \\
\text { pembelajaran anak usia } \\
\text { dini }\end{array}$ \\
\hline & & 9 & $\begin{array}{l}\text { Mengajukan permintaan } \\
\text { tenaga volunteer anak usia } \\
\text { dini pada lembaga dalam } \\
\text { dan luar negeri }\end{array}$ \\
\hline & & 10 & $\begin{array}{l}\text { Mengirimkan dosen } \\
\text { mengikuti international short } \\
\text { course program }\end{array}$ \\
\hline & & 14 & $\begin{array}{l}\text { Mengirimkan para dosen } \\
\text { S1 untuk melakukan studi } \\
\text { lanjut baik dalam maupun } \\
\text { luar negeri (S2 dan S3) }\end{array}$ \\
\hline & & 15 & $\begin{array}{l}\text { Workshop pelatihan } \\
\text { pembelajaran berbantuan } \\
\text { komputer dan internet } \\
\text { dalam perkuliahan }\end{array}$ \\
\hline \multirow[t]{8}{*}{4} & \multirow[t]{8}{*}{$\begin{array}{l}\text { Pencitraan } \\
\text { Publik }\end{array}$} & 6 & $\begin{array}{l}\text { Sosialisasi dan revitalisasi } \\
\text { laboratorium PAUD }\end{array}$ \\
\hline & & 8 & $\begin{array}{l}\text { Merintis beragam bentuk } \\
\text { layanan pendidikan anak } \\
\text { usia dini di masyarakat }\end{array}$ \\
\hline & & 22 & $\begin{array}{l}\text { Mengadakan kegiatan bakti } \\
\text { sosial di lembaga PAUD } \\
\text { pra-sejahtera }\end{array}$ \\
\hline & & 26 & $\begin{array}{l}\text { Mengadakan koordinasi } \\
\text { kegiatan PPL antara prodi } \\
\text { PAUD dengan stakeholder }\end{array}$ \\
\hline & & 35 & $\begin{array}{l}\text { Mengadakan } \\
\text { seminar/workshop dalam } \\
\text { rangka mempublikasikan } \\
\text { karya-karya inovatif. }\end{array}$ \\
\hline & & 36 & $\begin{array}{lr}\text { Memelihara } & \text { jalinan } \\
\text { kerjasama } & \text { dengan } \\
\text { departemen pendidikan } \\
\text { nasional (direktorat PAUD } \\
\text { dll) }\end{array}$ \\
\hline & & 37 & $\begin{array}{l}\text { Terlibat secara aktif di } \\
\text { dalam organisasi yang } \\
\text { berkecimpung di dunia } \\
\text { pendidikan anak usia dini } \\
\text { (Himpaudi, Forum PADU, } \\
\text { Konsorsium PAUD, } \\
\text { ISPAUDI) }\end{array}$ \\
\hline & & 38 & $\begin{array}{l}\text { Melakukan kegiatan } \\
\text { penyuluhan tentang pola } \\
\text { asuh kepada masyarakat } \\
\text { melalui kegiatan KKN } \\
\text { (kuliah Kerja Nyata) }\end{array}$ \\
\hline
\end{tabular}

\section{Penentuan Sasaran Strategik}

Berdasarkan critical process dan critical success matriks ditentukan Hoshin Objectives atau strategi Hoshin Plan, berdasarkan kriteria di atas selanjutnya dibentuk Hoshin Objectives, yang terdiri (1) penguatan tata kelola dan akuntabilitas PAUD; (2) meningkatkan kualitas SDM dalam memberikan pelayanan yang terbaik bagi pelanggan; (3) peningkatan keunggulan mutu, relevansi, dan daya saing; dan (4) pencitaan publik.

\section{Pembentukan Strategi}

Pembentukan strategi pelayanan didasarkan atas objectives yang telah disusun, sebagai petunjuk akan langkah-langkah yang hendak dilakukan untuk mencapai objectives. Pembentukan strategi pelayanan yang didasarkan atas permasalahan yang berhubungan dengan objectives itu sendiri yang mempunyai indikator kinerja yang terukur, hal ini dilakukan agar langkah yang diambil terukur, terarah, dan memudahkan dalam melakukan review atau perbaikan dikemudian hari.

\section{Tabel 5. Pembentukan Strategi Pelayanan pada Level Pertama}

\begin{tabular}{|c|c|}
\hline $\begin{array}{c}\text { Hoshin } \\
\text { Objectives }\end{array}$ & First Level Strategies \\
\hline $\begin{array}{l}\text { TUJUAN 1 } \\
\text { Pengingkatan } \\
\text { keunggulan } \\
\text { dan daya } \\
\text { saing }\end{array}$ & $\begin{array}{l}\Rightarrow \text { Meningkatkan mutu lulusan (kurikulum, } \\
\text { kompetensi umum, budaya akademik, } \\
\text { infrastruktur) } \\
\Rightarrow \text { Peningkatan kuantitas, kualitas, dan } \\
\text { variabilitas penelitian } \\
\Rightarrow \begin{array}{l}\text { Pengembangan model pengabdian pada } \\
\text { masyarakat }\end{array}\end{array}$ \\
\hline $\begin{array}{l}\text { TUJUAN 2 } \\
\text { Peningkatan } \\
\text { Tata kelola } \\
\text { dan } \\
\text { akuntabilitas } \\
\end{array}$ & $\begin{aligned} \rightarrow & \text { Reformasi birokrasi (SADA) } \\
\Rightarrow & \text { Optimalisasi LPjM } \\
\Rightarrow & \text { Pengembangan Sistem Informasi (SI) } \\
& \text { berbasis pada manajemen pengetahuan } \\
& \text { (Knowledge management) }\end{aligned}$ \\
\hline $\begin{array}{l}\underline{\text { TUJUAN } 3} \\
\text { Peningkatan } \\
\text { Sumber Daya } \\
\text { Manusia yang } \\
\text { unggul untuk } \\
\text { memberikan } \\
\text { pelayanan } \\
\text { yang terbaik } \\
\end{array}$ & $\begin{array}{l}\rightarrow \text { Peningkatan keahlian dosen dan tenaga } \\
\text { kependidikan } \\
\Rightarrow \text { Peningkatan keterampilan tenaga } \\
\text { administrasi } \\
\Rightarrow \text { Peningkatan kualitas mahasiswa dan } \\
\text { peran serta alumni }\end{array}$ \\
\hline $\begin{array}{l}\text { TUJUAN 4 } \\
\text { Meningkatkan } \\
\text { pencitraan } \\
\text { publik }\end{array}$ & $\begin{array}{l}\Rightarrow \text { Perluasan jejaring kemitraan dan } \\
\text { komitmen pelaksanaannya } \\
\Rightarrow \text { Perluasan akses bagi pendidikan yang } \\
\text { bermutu } \\
\Rightarrow \text { Perluasan dan peningkatan kualitas } \\
\Rightarrow \text { publikasi } \\
\Rightarrow \text { Peningkatan pelayanan prima }\end{array}$ \\
\hline
\end{tabular}

Sumber: diolah, Juni 2008 
Penyebaran strategi dilakukan dengan menetapkan level penyebaran pada struktur organisasi. Strategi yang telah dibentuk kemudian disebarkan sampai ke level dua saja untuk menghindari pengulangan objectives karena untuk level selanjutnya diaggap sebagai pelaksana untuk mencapai kebijakan yang telah ditentukan oleh atasannya. Selain itu, pada level kedua dianggap sudah mampu menentukan langkah selanjutnya dalam mencapai kebijakan yang telah digariskan oleh UNJ. Mekanisme penyebaran strategi dimulai dengan pembentukan strategi pada level pertama kemudian dilanjutkan dengan penyebaran strategi ke level yang berada di bawahnya. Strategi di level pertama akan menjadi tujuan pada level selanjutnya. Artinya, second level strategies harus dilakukan untuk mencapai first-level strategies dan seterusnya.

Tabel5. Penyebaran Strategi Pelayanan

\begin{tabular}{|c|c|c|}
\hline $\begin{array}{c}\text { Hoshin } \\
\text { Objectives }\end{array}$ & $\begin{array}{l}\text { First Level } \\
\text { Strategies }\end{array}$ & $\begin{array}{l}\text { Second Level } \\
\text { Strategies }\end{array}$ \\
\hline $\begin{array}{l}\text { TUJUAN1 } \\
\text { Pengingkatan } \\
\text { keunggulan } \\
\text { dan daya } \\
\text { saing }\end{array}$ & $\begin{array}{l}\rightarrow \text { Meningkatka } \\
\mathrm{n} \text { mutu } \\
\text { lulusan } \\
\text { (kurikulum, } \\
\text { kompetensi } \\
\text { umum, } \\
\text { budaya } \\
\text { akademik, } \\
\text { infrastruktur) }\end{array}$ & 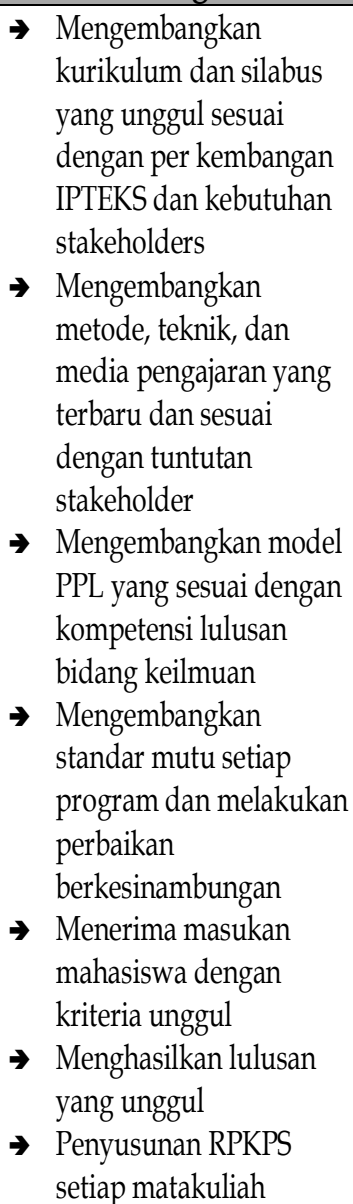 \\
\hline
\end{tabular}

\begin{tabular}{|c|c|c|}
\hline & $\begin{array}{l}7 \text { Peningkatan } \\
\text { kuantitas, } \\
\text { kualitas, dan } \\
\text { variabilitas } \\
\text { penelitian }\end{array}$ & 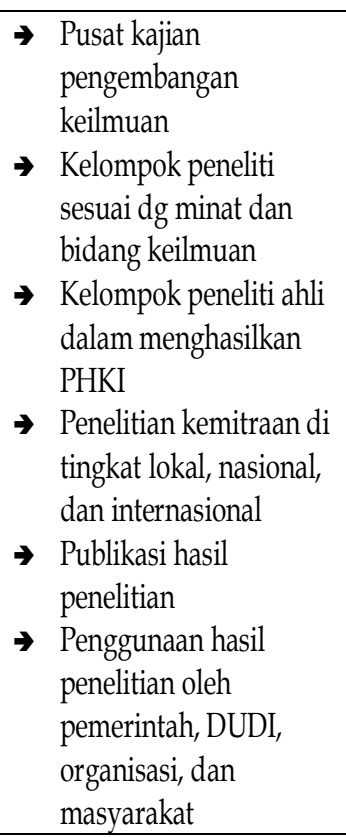 \\
\hline & $\begin{array}{l}7 \text { Pengembang } \\
\text { an model } \\
\text { pengabdian } \\
\text { pada } \\
\text { masyarakat }\end{array}$ & $\begin{aligned} & \text { - } \text { Meningkatkan kegiatan } \\
& \text { pengabdian kepada } \\
& \text { masyarakat atas dasar } \\
& \text { tanggungjawab sosial } \\
& \text { demi kepentingan } \\
& \text { rakyat. } \\
& \text { - } \text { Melaksanakan kegiatan } \\
& \text { pengabdian kepada } \\
& \text { masyarakat berdasarkan } \\
& \text { hasil-hasil penelitian } \\
& \text { untuk menyelesaikan } \\
& \text { masalah-masalah aktual } \\
& \text { di masyarakat } \\
& \Rightarrow \quad \text { Meningkatkan } \\
& \text { kompetensi sosial } \\
& \text { mahasiswa yang } \\
& \text { merupakan bagian } \\
& \text { integral dari proses } \\
& \text { pendidikan. } \\
& \Rightarrow \quad \text { Melaksanakan kegiatan } \\
& \text { pemberdayaan } \\
& \text { masyarakat yang } \\
& \text { berbasis partisipasi } \\
& \text { masyarakat. }\end{aligned}$ \\
\hline $\begin{array}{l}\text { TUJUAN 2 } \\
\text { Peningkatan } \\
\text { Tata kelola } \\
\text { dan } \\
\text { akuntabilitas }\end{array}$ & $\begin{array}{c}\text { Reformasi } \\
\text { birokrasi } \\
\text { (SADA) }\end{array}$ & 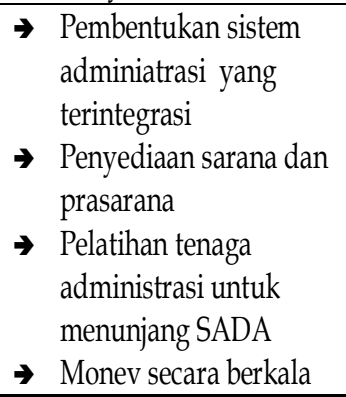 \\
\hline
\end{tabular}




\begin{tabular}{|c|c|c|}
\hline \multirow{3}{*}{$\begin{array}{l}\text { TUJUAN3 } \\
\text { Peningkatan } \\
\text { Sumber Daya } \\
\text { Manusia } \\
\text { yang unggul } \\
\text { untuk } \\
\text { memberikan } \\
\text { pelayanan } \\
\text { yang terbaik }\end{array}$} & $\begin{aligned} & \text { Optimalisasi } \\
& \text { LPjM }\end{aligned}$ & $\begin{array}{ll}\rightarrow & \text { Evaluasi di tingkat } \\
\text { jurusan secara berkala } \\
\text { memanfaatkan basis } \\
\text { data } \\
\rightarrow \text { Audit internal secara } \\
\text { beksinambungan }\end{array}$ \\
\hline & \begin{tabular}{|l} 
Pengembang \\
an Sistem \\
Informasi (SI) \\
berbasis pada \\
manajemen \\
pengetahuan \\
(Knowledge \\
management)
\end{tabular} & $\begin{array}{l}\rightarrow \text { Pembentukan tim } \\
\text { satuan tugas pembuatan } \\
\text { basis data dan } \\
\text { pengelolanya } \\
\Rightarrow \text { Penyusunan basis data } \\
\text { akademik, sarana dan } \\
\text { pasarana, SDM } \\
\Rightarrow \text { Penyediakan perangkat } \\
\text { TI dan jaringan }\end{array}$ \\
\hline & $\begin{array}{l}\Rightarrow \text { Peningkatan } \\
\text { keahlian } \\
\text { dosen dan } \\
\text { tenaga } \\
\text { kependidikan }\end{array}$ & 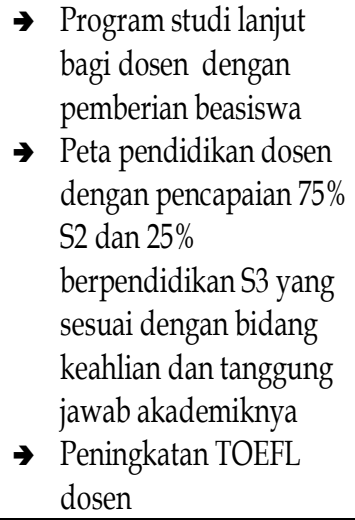 \\
\hline \multirow{3}{*}{$\begin{array}{l}\text { TUJUAN } 4 \\
\text { Meningkatka } \\
\text { n pencitraan } \\
\text { publik }\end{array}$} & 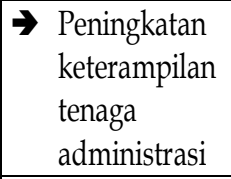 & $\begin{array}{ll}\rightarrow & \text { Program pelatihan TI } \\
& \text { untuk staff administrasi } \\
& \rightarrow \text { Program pelatihan } \\
& \text { layanan pulik } \\
\end{array}$ \\
\hline & $\begin{array}{l}\text { Peningkatan } \\
\text { kualitas } \\
\text { mahasiswa } \\
\text { dan peran } \\
\text { serta alumni }\end{array}$ & $\begin{aligned} \rightarrow & \text { Pembuatan website PG } \\
& \text { PAUD UNJ } \\
\Rightarrow & \text { Peningkatan rekrutment } \\
\text { mahasiswa baru yang } & \text { berkualitas } \\
\Rightarrow & \text { Pengaktifan kembali } \\
& \text { IKA FIP UNJ dengan } \\
& \text { menyelenggarakan temu } \\
& \text { alumni secara rutin }\end{aligned}$ \\
\hline & \begin{tabular}{|l} 
Perluasan \\
jejaring \\
kemitraan \\
dan \\
komitmen \\
pelaksanaann \\
ya
\end{tabular} & $\begin{array}{l}\text { - Pengalokasian dana } \\
\text { untuk program } \\
\text { pertukaran dosen dan } \\
\text { mahasiswa. } \\
\Rightarrow \text { Perintisan kerjasama } \\
\text { dengan perguruan } \\
\text { tinggi luar negeri } \\
\text { melalui berbagai } \\
\text { forum/seminar } \\
\text { internasional dan } \\
\text { melalui jaringan dosen } \\
\text { yang pernah studi lanjut } \\
\text { di luar negeri. }\end{array}$ \\
\hline
\end{tabular}

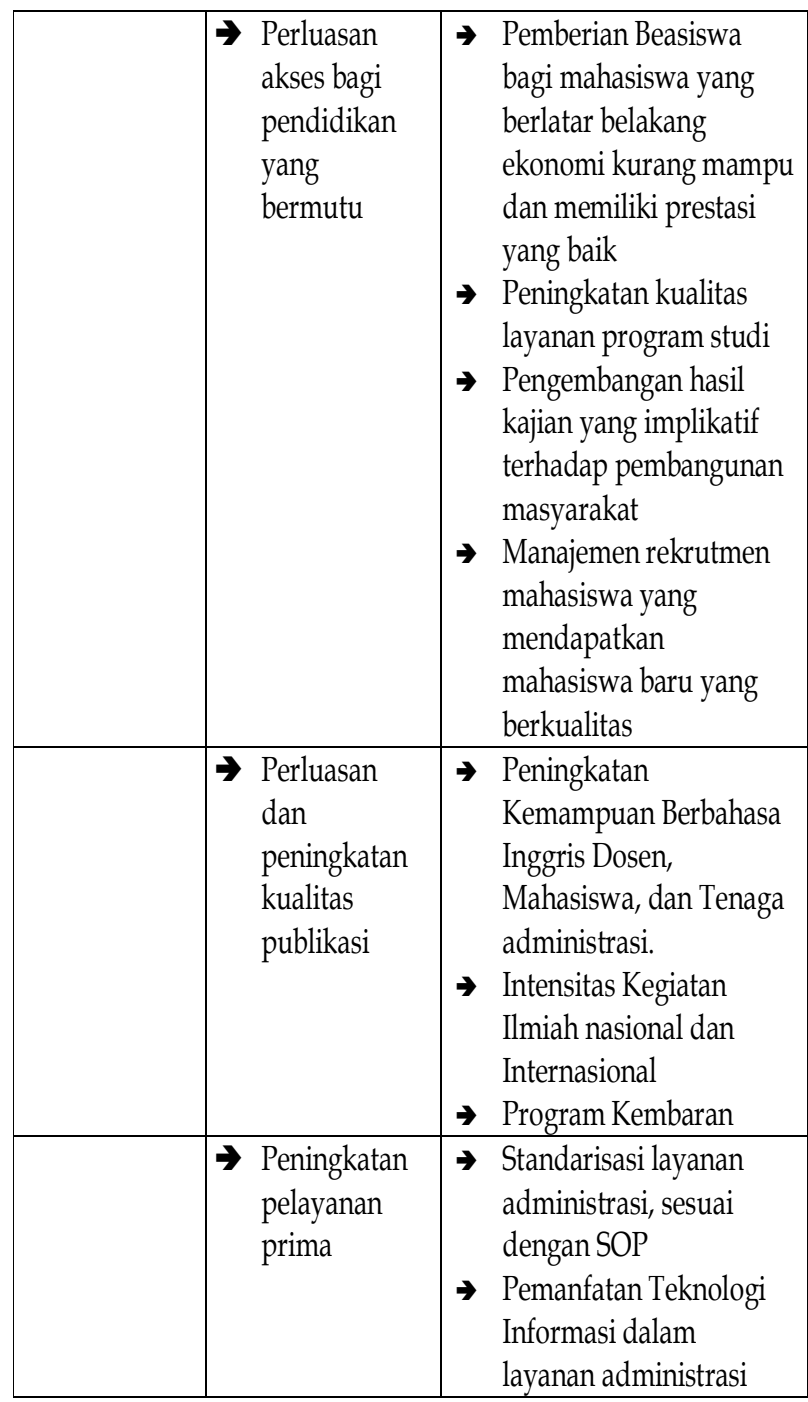

\section{KESIMPULAN}

Berdasarkan identifikasi terhadap keinginan dan kebutuhan mahasiswa PG PAUD FIP UNJ maka diperoleh informasi sebagai berikut (a) kualitas SDM yang menunjang (dosen dan karyawan) 14,28\%; (b) pembelajaran berlangsung dengan interaktif didukung dengan kurikulum yang sesuai dengan perkembangan IPTEKs dan tuntutan kerja, sehingga lulusan PG PAUD FIP UNJ memiliki mutu dan berdaya saing: 26,19\%; (c) efektifitas pengelolaan dan keramahan dalam melayani mahasiswa. Transparansi penilaian, SOP sehingga lembaga responsif terhadap kebutuhan mahasiswa: 9,52\%; (d) lulus tepat waktu dengan kualitas penelitian yang baik: 9,52\%; (e) ketersediaan sarana dan prasarana perkuliahan ditunjang dengan fasilitas teknologi informasi dan mampu memperoleh sumber pendanaan di luar institusi, seperti dana grand atau kerjasama dengan institusi lainnya: $35,72 \%$ dan (f) pencitraan publik: 4,77\%

Kinerja PG PAUD FIP UNJ dalam memberikan 
pelayanan pendidikan dinilai kurang memuaskan. Hal ini dapat terlihat dari tingginya gap antara ekspektasi dan persepsi terhadap kualitas layanan. Gap terbesar adalah 4 sebanyak 2,08\%, gap 3 sebanyak $41,67 \%$. Nilai Gap terkecil adalah 2 sebanyak 56,25\%

3. Berdasarkan hasil identifikasi terhadap isu-isu penting dalam upaya meningkatkan kualitas layanan pendidikan diperoleh informasi berupa kriteria bentuk layanan yang perlu ditingkatkan kinerjanya; (1) peningkatan mutu relevansi dan daya saing dapat memenuhi kebutuhan pelanggan sebesar 33,687\%; (2) penguatan tatakelola dan akuntabilitas memiliki bobot sebesar 28,291; (3) Pencitraan publik memiliki konstribusi dalam memenuhi kebutuhan pelanggan adalah 16,435\% dan (4) pengembangan sumber daya manusia memiliki porsi sebesar $21,832 \%$.

4. Proses perencanaan strategi yang diusulan strategi dan penyebarannya samapi level 2 dalam struktur organisasi PG PAUD. Usulan tersebut terdiri dari 13 strategi pada level pertama dan 57 strategi pada level kedua. Usulan Usulan strategi tersebut disesuaikan dengan visi dan misi lembaga yaitu mengantisipasi tantangan dan peluang di era globalisasi melalui peningkatan pelayanan dan penyelenggaraan pengajaran, penelitian, dan pengabdian masyarakat untuk menghasilkan SDM yang memiliki keunggulan akademis, professional di bidang PG PAUD dengan memenuhi kriteria ke empat strategik vision untuk memenuhi layanan: jasa intrakulikuler, jasa ektrakulikuler, jasa penelitian, jasa pengabdian masyarakat, jasa kebijakan umum dan jasa administrasi.

\section{DAFTAR PUSTAKA}

Amin W Tunggal, W., (2002). Manajemen mutu terpadu, Jakarta: Rineka Cipta.

BAN-PT (2007) Naskah akademik akreditasi institusi perguruan tinggi 2007.

Buku Pedoman Akademik Universitas Negeri Jakarta (2008). Universitas Negeri Jakarta.

Cohen. (1995). QFD: How to make QFD work for you. Addison Wesley.

Cohenu, Lou, (1996). QFD how to make your QFD work for you. NY: Addison-Wesley Publishing Company.

Fred R. David. (2007). Strategic management conceps and cases eleven edition. New Jersey: Pearson Prentice Hall
Gaspersz, Vincent, (2001). Metode untuk peningkatan kualitas, Jakarta: Gramedia Pustaka Utama.

Gronross C, (2001). Service management and marketing. England: John Wiley\&Son

G. Thomas Cumming \& Christopher G. Worley. (2005).Organization deplopment and change, eighth edition.

James, F.A \& F.Mona J, (2006). Service management; Operation, strategy, information technology. USA: Mc Graw Hill.

J.B, Revelle, Moran JW \& Cox C.A (1998). The QFD handbook. Canada:John Wiley\&Sons Inc.

Richard B. Chase, F. Robert Jacobs \& Nicholas J. Aquilano, (2004). Operation management for competitive advantage tenthedition. New York: Mc Graw Hill

Sekaran, Uma (1992) Research methods for business, (New York: Jhon Wiley and Son Inc).

Soin \& Sarv Sigh (1993). Total quality control essentials: key elements metodologies and managing for succses. Singapore: Mc Graw Hill.

Tim Kemahasiswaan. (2006). Strategi pengembangan kemahasiswaan universitas negeri jakarta. Jakarta: UNJ

Tim Pengembang UNJ, (2007). Portofolio akreditasi institusi universitas negeri jakarta. Jakarta: UNJ

Tjiptono, F \& Diana,A, (2000), Total quality management. Yogyakarta: Andi Penerbit Andi Yogyakarta, Edisi Revisi.

\section{Jurnal}

Ashok Kumar, Jiju Antony dan Tej S. Dhakar, Integrating quality fuctional deployment and bechmarking to actieve greater profitability, Bechmarking: An International Journal Vol.13 No. 3, 2006

Gonzalez M.E, Costumer stisfaction using QFD: an ebanking case", Managing Service Quality, Vol. 14 No.4

Hwarang, HB., C Teo., Translating custumers voices into operations requirement: a QFD application in hinger education. International Journal of Quality \& Reability Management Vol.1 No.20

Shie-ming Chou, Evaluating the service quality of undergraduate nursing education in Taiwan-using quality fuction deployment, Journal Nurse Education Today: 2004 
Dra. Nurbiana Dhieni, M. Pd, lahir di Medan pada tanggal 18 April 1965. Saat ini menjabat sebagai Sekretaris Jurusan PG PAUD FIP UNJ dan sebagai dosen PG PAUD FIP UNJ. 